\title{
Effect of Weed Management Practices on Weed Studies, Yield and Nutrient Depletion in Clusterbean [Cyamopsis tetragonoloba (L.) Taub]
}

\author{
Bharat Lal Meena ${ }^{1}$, B. L. Dudwal ${ }^{1}$, Kamal Garg ${ }^{2 *}$, \\ Monu Jorwal $^{1}$ and Ram Krishna Shekhawat ${ }^{1}$ \\ ${ }^{1}$ Department of Agronomy, SKNAU Jobner-303329, India \\ ${ }^{2}$ Department of Agronomy, IARI New Delhi-110012, India \\ *Corresponding author
}

\section{Keywords}

Cluster bean, nutrient depletion, grain yield and weed studies

Article Info

\section{Accepted:}

22 January 2021

Available Online:

10 February 2021
A field experiment was conducted at Agronomy farm, S.K.N. College of Agriculture, Jobner, Jaipur (Rajasthan) during kharif season of 2018 to study the effect of weed management practices on weed studies, grain yield and nutrient depletion in clusterbean. The experiment comprising of 9 treatments i.e. Weedy check, One hand weeding at 25 DAS, Two hand weedings at 25 and 45 DAS, Pendimethalin @ $750 \mathrm{~g}$ a.i./ha (PE), Imazethapyr @ $75 \mathrm{~g}$ a.i./ha (PoE), Quizalofop-p- ethyl@ 37.5 g a.i./ha (PoE), Pendimethalin@ $750 \mathrm{~g}$ a.i./ha (PE) + Quizalofop-p-ethyl@ $37.5 \mathrm{~g}$ a.i./ha (PoE), Pendimethalin @ 750 g a.i./ha (PE) + Imazethapyr @ 75 g a.i./ha (PoE), Pendimethalin 30 EC + Imazethapyr 2 EC (RM) @ $750 \mathrm{~g}$ a.i./ha as pre- emergence was laid out in randomized block design and replicated thrice. The results showed that weed management practices markedly reduced crop-weed competition. Both hand weedings at 25 and $45 \mathrm{DAS}$ and pendimethalin @ $750 \mathrm{~g}$ a.i./ha (PE) + imazethapyr @ $75 \mathrm{~g}$ a.i./ha $(\mathrm{PoE})$ treatments were found significantly superior in reducing weed density, dry weight and nutrient depletion by weeds as well as higher weed control efficiency than weedy check and all other single herbicide applied treatments viz. Pendimethalin @ $750 \mathrm{~g}$ a.i./ha (PE), Imazethapyr @ 75 g a.i./ha (PoE), Quizalofop-p-ethyl @ 37.5 g a.i./ha (PoE) and one hand weeding at 25 DAS. The grain yield was significantly higher under the treatment two hand weedings at 25 and 45 DAS over weedy check and superior to all single herbicide applied treatments and one hand weeding at $25 \mathrm{DAS}$, but it was at par with treatments pendimethalin @ $750 \mathrm{~g}$ a.i./ha (PE) + imazethapyr @ $75 \mathrm{~g}$ a.i./ha (PoE), pendimethalin (PE) @ $750 \mathrm{~g}$ a.i./ha + quizalofop-p-ethyl @ $37.5 \mathrm{~g}$ a.i./ha (PoE), pendimethalin $30 \mathrm{EC}+$ imazethapyr 2 EC (RM) @ $750 \mathrm{~g}$ a.i./ha as (PE). 


\section{Introduction}

Clusterbean [Cyamopsis tetragonoloba (L.) Taub] popularly known by its vernacular name "Guar" is an important legume crop mainly grown under rainfed conditions of arid and semi- arid region of tropical India. Clusterbean is a native to the Indian subcontinent. It is considered as one of the most drought tolerant grain legume crop. The word "guar" represents its derivation from sanskrit word "Gauaahar" which means cow fodder or otherwise fodder of the livestock. It is drought hardy, deep rooted and can be grown as summer annual legume. In India, clusterbean is grown on 5.6-million-hectare area with the annual production of 2.7 million tonnes and productivity of $482 \mathrm{~kg} / \mathrm{ha}$ (Anonymous, 2016-17a). India is one of the main producers of clusterbean contributing up to 80 per cent of total production of world, whereas Rajasthan occupies the largest area (4.6 mha) (82.1 per cent) under clusterbean cultivation in the country with the annual production of 2.2 million tonnes and productivity of $488 \mathrm{~kg} / \mathrm{ha}$ (Anonymous, 201617b). In India, this crop is mostly grown in the dry areas of Rajasthan, Haryana, Gujarat and Punjab and to a limited extent in U.P. and M.P. In Rajasthan, clusterbean is mainly grown in Barmer, Churu, Sriganganagar, Nagaur, Jalore, Sikar, Jaisalmer, Bikaner, Jaipur and Alwar districts. Among the various factors responsible for low productivity, soil moisture availability, weed infestation and low fertility are regarded as the most limiting factors because crops are very much sensitive to crop-weed competition, fertility and soil moisture stress particularly at their critical growth stages. Among these also weeds cause losses up to a greater extent which leads to the lower productivity of the crop. As guar is a rainy season crop and due to frequent rains, the weed population increases tremendously which compete for nutrients, moisture and space with crop causing considerable yield reduction. Critical crop weed competition in guar field is from 20-30 DAS (Patel et al., 2005). Clusterbean either grown during summer or kharif season suffers severely by grassy, broad leaved and sedges. Season long competition with weeds in clusterbean causes severe yield reduction ranging from $29-48$ per cent and severity may even be higher (70$98 \%$ ) depending on the weed infestation (Sonani et al., 1985).

Generally manual weeding is very effective for controlling all type of weeds. Two manual weedings given at 25 and 45 DAS are sufficient to keep the crop weed free. However, sometimes due to non-availability of labour, herbicides like pendimethalin @ 2.5 to $3.30 \mathrm{~L} / \mathrm{ha}$ can be applied by mixing with $500 \mathrm{~L}$ of water as pre-emergence application (within 2 days of sowing). After that one manual weeding at 30 DAS or post emergence application of imazethapyr @ 400 gm/ha mixing with 500 litre water at 20-25 DAS can be applied for controlling weeds in clusterbean field. Among different weed management practices, hand weeding is traditional and effective option but unavailability of labour at peak weeding periods and increasing labour cost impose major limitations on economic feasibility of manual weeding. Therefore, it is imperative that the critical period of crop weed competition need to be determined so as to obtain the maximum benefits from effective and efficient weed management practices. Various methods followed to manage the weeds have their own merits and demerits. The use of herbicides holds a good promise for timely, effective and efficient weed control where, labour is scarce and expensive. The choice of herbicide for a particular situation will depend upon the climate, soil type, prevalent weed species, crop cultivar and method of propagation and management. A single application of any herbicide has not been effective in curbing the weed menace with diversified weed flora. Hence, it is 
worthwhile to use different herbicidal mixtures and their sequential application for effective weed control. In recent years, a mixture of Pendimethalin 30 EC + Imazethapyr 2 EC (RM) @ 750 g a.i./ha (VALOR 32) as pre-emergence has performed well in leguminous crops as pre-emergence herbicide. It acts as a PPO inhibitor in plants and it provides selective broadleaf weed control in various crops. Hence, in the present study, different effects of weed management practices are evaluated under semi-arid conditions of Rajasthan on weed studies, grain yield and nutrient depletion in clusterbean.

\section{Materials and Methods}

The experiment was conducted during kharif season 2018 at Agronomy farm, S.K.N. College of Agriculture, Jobner, Jaipur (Rajasthan). The soil of the experimental field was loamy-sand in texture, alkaline in reaction $(\mathrm{pH} 8.25)$, poor in organic carbon $(0.23 \%)$, low in available nitrogen (124.7 $\mathrm{kg} / \mathrm{ha})$, medium in phosphorus (16.10 kg/ha) and potassium $(150.24 \mathrm{~kg} / \mathrm{ha})$. The experiment comprising of 9 treatments i.e. Weedy check, One hand weeding at 25 DAS, Two hand weedings at 25 and 45 DAS, Pendimethalin@ $750 \mathrm{~g}$ a.i./ha (PE), Imazethapyr @ $75 \mathrm{~g}$ a.i./ha (PoE), Quizalofop-p- ethyl@ 37.5 g a.i./ha (PoE), Pendimethalin @ $750 \mathrm{~g}$ a.i./ha $(\mathrm{PE})+$ Quizalofop-p-ethyl@ 37.5 g a.i./ha (PoE), Pendimethalin @ 750 g a.i./ha (PE) + Imazethapyr @ 75 g a.i./ha (PoE), Pendimethalin 30 EC + Imazethapyr 2 EC (RM) @ $750 \mathrm{~g}$ a.i./ha as pre- emergence was laid out in randomized block design and replicated thrice. The plot size was $4.0 \mathrm{~m}$ x 3.0 $\mathrm{m}$. Clusterbean crop was sown on $8^{\text {th }}$ July 2018. The seeds of clusterbean crop were sown by 'kera' method at a spacing $30 \mathrm{~cm} \times 10$ $\mathrm{cm}$ with the seed rate $20 \mathrm{~kg}$ seed/ha. A uniform dose of $20 \mathrm{~kg} \mathrm{~N}$ through urea was applied in furrows at the time of sowing after adjusting the $\mathrm{N}$ received from DAP. The uniform dose of $40 \mathrm{~kg} \mathrm{P}_{2} \mathrm{O}_{5}$ was applied through DAP. Thinning, hoeing and weeding were done after 25 days of sowing to maintain recommended spacing and proper aeration. Weed density was taken at 30 and 60 DAS from two random spots in each plot by counting the number of weeds per quadrate of $1.0 \mathrm{~m}^{2}$ and the average was computed. Weed samples from two randomly selected spots in each plot were taken at 30 and 60 DAS with the help of $1.0 \mathrm{~m}^{2}$ quadrate and the average was worked out. The samples so collected were subjected to sun dry for sufficient time, weighed and average was computed as dry matter $\mathrm{kg} / \mathrm{ha}$. In order to evaluate the weed control treatments for their efficacy weed control efficiency of each treatment was calculated by using the following formula given by Varshney, (1990). Weed index was calculated by the following formula advocated by Yadav and Mishra, (1982). Clusterbean crop was harvested on $28^{\text {th }}$ October, 2018 after leaving two border rows on each side of plot along the length on both sides, a net area of $3.0 \mathrm{~m} \times 1.8 \mathrm{~m}$ was harvested separately from each plot to assess the grain yields from net plot area. In each plot, bundles were tied and tagged properly and transported on threshing floor for proper sun drying. The total biomass harvested from each net plot was threshed, cleaned and dried. The clean grain obtained from individual plot was weighed separately and weight recorded as grain yield (kg/plot). After recording dry matter accumulation by weeds at harvest, samples were ground for estimation of $\mathrm{N}, \mathrm{P}$ and $\mathrm{K}$ contents in weeds. Estimation of $\mathrm{N}$ was done by colorimetric method using Nessler's reagent to develop colour (Lindner 1949). P content was determined by Vanadomolybdo phosphoric acid yellow colour method (Richards 1968) while K by flame photometer (Jackson 1973) method. Representative samples of weed dry matter taken from each plot at 60 DAS stage were processed and subjected to chemical analyses for their $\mathrm{N}, \mathrm{P}$, and $\mathrm{K}$ concentration 
with standard methods. The depletion of nutrients by weeds at harvest stage was estimated by using the following formula:

Nutrient uptake by weeds (kg/ha)

Nutrient content in $\mathrm{x}$ weed dry weight weed $(\%)(\mathrm{kg} / \mathrm{ha})$

100

\section{Results and Discussion}

\section{Effect on weed studies}

Weed density recorded at 30 and 60 DAS (Table 1) revealed that weed population was considerably reduced under effective weed management practices. At 30 DAS treatment pendimethalin @ $750 \mathrm{~g}$ a.i./ha (PE) + imazethapyr @75 g a.i./ha (PoE) recorded lowest density (3.30 plants $\left./ \mathrm{m}^{2}\right)$ of weeds compared to rest of the weed control treatments because first hand weeding was performed just few days before observation (30 DAS after sowing), which gave the best weed management among all the treatments followed by pendimethalin (PE) @ $750 \mathrm{~g}$ a.i./ha + quizalofop-p-ethyl @ 37.5 g a.i./ha (PoE) as the next best treatment. At 60 DAS the significantly lowest weed density (2.12 plants $/ \mathrm{m}^{2}$ ) was recorded with treatment two hand weeding at 25 and 45 DAS (W3) $f b$ treatment pendimethalin @ $750 \mathrm{~g}$ a.i./ha (PE) + imazethapyr @ $75 \mathrm{~g}$ a.i./ha (PoE), pendimethalin (PE) @ 750 g a.i./ha + quizalofop-p-ethyl @ $37.5 \mathrm{~g}$ a.i./ha (PoE), pendimethalin $30 \mathrm{EC}+$ imazethapyr $2 \mathrm{EC}$ (RM) @ $750 \mathrm{~g}$ a.i./ha as(PoE) and these were found statistically at par with each other and were superior over rest of the treatments. While, the highest weed density at 30 and 60 DAS $\left(11.47\right.$ and 12.64 plants $\left./ \mathrm{m}^{2}\right)$ was recorded under weedy check (W1) this is because of uncontrolled weed growth in these plots. Similar results were observed by Yadav et al., (2011) and Jha and Soni, (2013).
Among the weed management practices, treatment two hand weeding at 25 and 45 DAS (W3) $f b$ treatment pendimethalin @ $750 \mathrm{~g}$ a.i./ha (PE) + imazethapyr @ 75 g a.i./ha (PoE), pendimethalin (PE) @ $750 \mathrm{~g}$ a.i./ha + quizalofop-p-ethyl @ $37.5 \mathrm{~g}$ a.i./ha (PoE), pendimethalin $30 \mathrm{EC}+$ imazethapyr $2 \mathrm{EC}$ (RM)@ 750 g a.i./ha as (PoE) showed their superiority over rest of the all single treatments and weedy check in reduction of dry weight of weeds recorded at 30 and 60 DAS. However, treatment weedy check (W1) recorded significantly highest weed dry matter $\left(9.51\right.$ and $10.31 \mathrm{~g} / \mathrm{m}^{2}$ at 30 and 60 DAS respectively) among all the weed management practices (Table 1). The increase in population and dry matter production of weeds to such a high level under weedy check may be attributed to uninterrupted weed growth throughout the crop season. Pendimethalin exerts its herbicidal effect by inhibiting both root and shoot growth and development through disruption of ATP formation and inhibition of cell division in the meristematic tissues. The growth is inhibited directly following absorbing through hypocotyls and shoot region. The plants die shortly after germination or emergence from the soil. Similar results were observed by Yadav et al., (2011), Raju et al., (2017) and Singh et al., (2018).

Similarly, the weed control efficiency recorded at 60 DAS was significantly influenced by different weed management practices have been cited in table 1 . The highest weed control efficiency $(88.94 \%)$ was recorded under two hand weeding at 25 and 45 DAS treatment (W3) followed by treatment pendimethalin @ 750 g a.i./ha (PE) + imazethapyr @ $75 \mathrm{~g}$ a.i./ha (PoE), pendimethalin (PE) @ $750 \mathrm{~g}$ a.i./ha + quizalofop-p-ethyl @ $37.5 \mathrm{~g}$ a.i./ha (PoE), pendimethalin $30 \mathrm{EC}+$ imazethapyr $2 \mathrm{EC}$ (RM) @ $750 \mathrm{~g}$ a.i./ha as (PoE). Among the single application of herbicides, imazethapyr 
@ $75 \mathrm{~g}$ a.i./ha (PoE) recorded the highest weed control efficiency (53.01\%) followed by pendimethalin @ 0 g a.i./ha (PE), quizalofop-p-ethyl @ $37.5 \mathrm{~g}$ a.i./ha (PoE) and one hand weeding at 25 DAS, but these were at par with each other. However, the lowest weed control efficiency (42.35\%) was recorded with one hand weeding at 25 DAS (W2). Hand weedings twice (25 and 45 DAS) removed the weeds completely and created condition which were more favourable for crop growth and ultimately resulted in the lowest density of later emerged weeds and their lowest biomass with higher weed control efficiency during the crop growth period.

Higher efficacy of pendimethalin + imazethapyr (RM) at early stage might be due to the effectiveness of molecules towards weeds. These results are akin to those reported by Punia et al., (2011), Raju et al., (2017) and Singh et al., (2018).

The highest weed index (59.21\%) was recorded with weedy check (W1) followed by one hand weeding at 25 DAS $(35.38 \%)$. The treatment pendimethalin @ $750 \mathrm{~g}$ a.i./ha (PE) + imazethapyr@75 g a.i./ha (PoE) recorded the lowest weed index (2.89\%) followed by pendimethalin (PE) @ 750 g a.i./ha + quizalofop-p-ethyl @ 37.5 g a.i./ha (PoE), pendimethalin $30 \mathrm{EC}+$ imazethapyr $2 \mathrm{EC}$ (RM) @ $750 \mathrm{~g}$ a.i./ha as (PoE) but these are statistically at par with each other. Among single application of herbicides, the lowest weed index was recorded under imazethapyr @ $75 \mathrm{~g}$ a.i./ha (PoE) (27.80\%) which was statistically at par with pendimethalin @ $750 \mathrm{~g}$ a.i./ha (PE), quizalofop-p-ethyl @ $37.5 \mathrm{~g}$ a.i./ha (PoE) and One hand weeding at 25 DAS with weed index of 28.16, 30.69, 35.38 $\%$ respectively. This was due to controlling weeds and good weed management. These treatments showed high seed yield. Present results are in close accordance with findings of Raju et al., (2017) and Singh et al., (2018).

\section{Effect on grain yield}

Different weed management practices showed conspicuous effect on grain yield. The data in table 2 revealed that the significantly the highest grain yield (1385 kg/ha) was recorded with two hand weeding at 25 and 45 DAS (W3) $f b$ treatments pendimethalin@750 g a.i./ha (PE) + imazethapyr @ 75 g a.i./ha (PoE), pendimethalin (PE) @ $750 \mathrm{~g}$ a.i./ha + quizalofop-p-ethyl @ $37.5 \mathrm{~g}$ a.i./ha (PoE), pendimethalin $30 \mathrm{EC}+$ imazethapyr $2 \mathrm{EC}$ (RM) @ $750 \mathrm{~g}$ a.i./ha as (PoE) and these were found statistically at par with each other and were superior over rest of the treatments. Presence of weeds in treatment weedy check (W1) throughout the crop season reduced the grain yield of clusterbean. The minimum grain yield $(565 \mathrm{~kg} / \mathrm{ha})$ was recorded under weedy check (W1). These results are in accordance with the findings of Punia et al., (2011), Yadav et al., (2011), Jha and Soni, (2013), Bhadoria et al., (2000) and Patel et al., (2018).

Removal of weeds at early stage in the season reduced crop weed competition at the lowest possible limit and provided almost weed free environment. Due to controlling weeds, higher growth and yield parameters of cluster bean was observed which were probable reasons for higher grain yield in treatment two hand weeding at 25 and 45 DAS (W3).

These results are in accordance with the findings of Yadav et al., (2011) and Singh et al., (2018). The pre-emergence application of pendimethalin + imazethapyr (RM) gave excellent control and suppression of weeds in the season was probably effective against secondary weed emergence at 10 to 15 DAS stage onwards due to persistent of imazethapyr for long period. The weed management schedule having low weed biomass and higher weed control efficiency would provide favourable situation for maximization of cluster bean yield potential. 
Table.1 Effect of weed management practices on weed density, weed dry matter, weed control efficiency and weed index in clusterbean

\begin{tabular}{|c|c|c|c|c|c|c|}
\hline \multirow[t]{2}{*}{ Treatments } & \multicolumn{2}{|c|}{ Weed density $/ \mathrm{m}^{2}$ area } & \multicolumn{2}{|c|}{ Weed dry matter $\left(\mathrm{g} / \mathrm{m}^{2}\right)$} & \multirow{2}{*}{$\begin{array}{l}\text { Weed control } \\
\text { efficiency }(\%)\end{array}$} & \multirow{2}{*}{$\begin{array}{l}\text { Weed index } \\
(\%)\end{array}$} \\
\hline & 30 DAS & 60 DAS & 30 DAS & 60 DAS & & \\
\hline Weedy check & $\begin{array}{c}11.47 \\
(130.98)\end{array}$ & $\begin{array}{c}12.64 \\
(159.25)\end{array}$ & $\begin{array}{c}9.51 \\
(89.85)\end{array}$ & $\begin{array}{c}10.31 \\
(105.83)\end{array}$ & 0.00 & 59.21 \\
\hline One hand weeding at 25 DAS & $\begin{array}{c}5.45 \\
(29.15)\end{array}$ & $\begin{array}{c}6.63 \\
(43.42)\end{array}$ & $\begin{array}{c}5.68 \\
(31.79)\end{array}$ & $\begin{array}{c}5.94 \\
(34.84)\end{array}$ & 42.35 & 35.38 \\
\hline Two hand weeding at 25 and 45 DAS & $\begin{array}{c}5.44 \\
(29.10)\end{array}$ & $\begin{array}{c}2.12 \\
(4.00)\end{array}$ & $\begin{array}{c}5.67 \\
(31.70)\end{array}$ & $\begin{array}{c}1.14 \\
(0.80)\end{array}$ & 88.94 & 0.00 \\
\hline Pendimethalin@ 950 g a.i./ha (PE) & $\begin{array}{c}4.64 \\
(21.00)\end{array}$ & $\begin{array}{c}5.06 \\
(25.10)\end{array}$ & $\begin{array}{c}4.65 \\
(21.09)\end{array}$ & $\begin{array}{c}4.92 \\
(23.70)\end{array}$ & 52.29 & 28.16 \\
\hline Imazethapyr @ 75 g a.i./ha (PoE) & $\begin{array}{c}4.42 \\
(19.01)\end{array}$ & $\begin{array}{c}4.82 \\
(22.71)\end{array}$ & $\begin{array}{c}4.50 \\
(19.71)\end{array}$ & $\begin{array}{c}4.85 \\
(22.98)\end{array}$ & 53.01 & 27.80 \\
\hline $\begin{array}{c}\text { Quizalofop-p-ethyl@ } 37.5 \text { g a.i./ha } \\
\text { (PoE) }\end{array}$ & $\begin{array}{c}4.93 \\
(23.80)\end{array}$ & $\begin{array}{c}5.41 \\
(28.72)\end{array}$ & $\begin{array}{c}4.86 \\
(23.09)\end{array}$ & $\begin{array}{c}5.17 \\
(26.19)\end{array}$ & 49.90 & 30.69 \\
\hline $\begin{array}{c}\text { Pendimethalin@ } 750 \text { g a.i./ha (PE) + } \\
\text { Quizalofop-p-ethyl@ } 37.5 \text { g a.i./ha } \\
\text { (PoE) }\end{array}$ & $\begin{array}{c}3.41 \\
(11.15)\end{array}$ & $\begin{array}{c}3.94 \\
(14.99)\end{array}$ & $\begin{array}{l}2.67 \\
(6.64)\end{array}$ & $\begin{array}{c}3.53 \\
(11.96)\end{array}$ & 65.77 & 7.58 \\
\hline $\begin{array}{l}\text { Pendimethalin @ } 750 \text { g a.i./ha }(\mathrm{PE})+ \\
\text { Imazethapyr @ } 75 \text { g a.i./ha (PoE) }\end{array}$ & $\begin{array}{c}3.30 \\
(10.42)\end{array}$ & $\begin{array}{c}3.73 \\
(13.40)\end{array}$ & $\begin{array}{c}2.26 \\
(4.62)\end{array}$ & $\begin{array}{c}2.90 \\
(7.90)\end{array}$ & 71.89 & 2.89 \\
\hline $\begin{array}{l}\text { Pendimethalin } 30 \text { EC + Imazethapyr } \\
2 \text { EC (RM) @ } 750 \text { g a.i./ha (PE) }\end{array}$ & $\begin{array}{c}4.00 \\
(15.54)\end{array}$ & $\begin{array}{c}4.52 \\
(19.90)\end{array}$ & $\begin{array}{c}3.37 \\
(10.88)\end{array}$ & $\begin{array}{c}4.63 \\
(20.96)\end{array}$ & 55.08 & 8.66 \\
\hline $\mathrm{SEm} \pm$ & 0.27 & 0.27 & 0.25 & 0.24 & 2.98 & 1.31 \\
\hline $\mathrm{CD}(\mathrm{P}=\overline{\mathbf{0 . 0 5}})$ & 0.80 & 0.80 & 0.76 & 0.73 & 8.92 & 3.91 \\
\hline $\mathrm{CV}(\%)$ & 8.86 & 8.56 & 9.10 & 8.78 & 9.68 & 10.16 \\
\hline
\end{tabular}

Data subjected to $\sqrt{\mathrm{x}}+0.5$ transformation and figures in parenthesis are original weed count $/ \mathrm{m}^{2}$ area 
Table.2 Effect of weed management practices on grain yield and N, P and K concentration and their depletion by weed in clusterbean

\begin{tabular}{|c|c|c|c|c|c|c|c|}
\hline \multirow[t]{2}{*}{ Treatments } & \multirow[t]{2}{*}{ Grain yield (kg/ha) } & \multicolumn{3}{|c|}{ Concentration in weed $(\%)$} & \multicolumn{3}{|c|}{ Depletion by weed (kg/ha) } \\
\hline & & $\mathbf{N}$ & $\mathbf{P}$ & $\mathbf{K}$ & $\mathbf{N}$ & $\mathbf{P}$ & $\mathbf{K}$ \\
\hline Weedy check & 565 & 1.867 & 0.310 & 1.675 & 197.58 & 32.81 & 177.27 \\
\hline One hand weeding at 25 DAS & 895 & 1.863 & 0.290 & 1.654 & 64.91 & 10.10 & 57.63 \\
\hline Two hand weeding at 25 and 45 DAS & 1385 & 1.800 & 0.236 & 1.630 & 1.44 & 0.19 & 1.30 \\
\hline Pendimethalin @ 750 g a.i./ha (PE) & 995 & 1.855 & 0.248 & 1.648 & 43.96 & 5.88 & 39.06 \\
\hline Imazethapyr @ 75 g a.i./ha (PoE) & 1000 & 1.849 & 0.242 & 1.645 & 42.49 & 5.56 & 37.80 \\
\hline $\begin{array}{c}\text { Quizalofop-p-ethyl@ } 37.5 \text { g a.i./ha } \\
\text { (PoE) }\end{array}$ & 960 & 1.860 & 0.251 & 1.645 & 48.71 & 6.57 & 43.08 \\
\hline $\begin{array}{c}\text { Pendimethalin @ } 750 \text { g a.i./ha }(\mathrm{PE})+ \\
\text { Quizalofop-p-ethyl@ } 37.5 \text { g a.i./ha (PoE) }\end{array}$ & 1280 & 1.845 & 0.238 & 1.636 & 22.07 & 2.85 & 19.57 \\
\hline $\begin{array}{l}\text { Pendimethalin @ } 750 \text { g a.i./ha }(\mathrm{PE})+ \\
\text { Imazethapyr @ } 75 \text { g a.i./ha }(\mathrm{PoE})\end{array}$ & 1345 & 1.834 & 0.237 & 1.633 & 14.49 & 1.87 & 12.90 \\
\hline $\begin{array}{l}\text { Pendimethalin } 30 \text { EC + Imazethapyr } \\
2 \text { EC (RM) @ } 750 \text { g a.i./ha (PE) }\end{array}$ & 1265 & 1.852 & 0.240 & 1.641 & 38.82 & 5.03 & 34.40 \\
\hline $\mathrm{SEm} \pm$ & 50.6 & 0.092 & 0.013 & 0.082 & 3.05 & 0.48 & 2.72 \\
\hline $\mathrm{CD}(\mathrm{P}=\mathbf{0 . 0 5})$ & 151.6 & NS & NS & NS & 9.13 & 1.43 & 8.16 \\
\hline CV (\%) & 8.1 & 8.655 & 8.533 & 8.666 & 10.01 & 10.52 & 10.04 \\
\hline
\end{tabular}

NS- Non-significant 
Effect on nutrient concentration and their depletion by weeds

The data in table 2 revealed that $\mathrm{N}, \mathrm{P}$ and $\mathrm{K}$ depletion by weeds almost followed the footsteps of weed biomass in trend. It is clear from the data that the maximum depletion of 194.09, 24.92 and $172.50 \mathrm{~kg} / \mathrm{ha} \mathrm{N}, \mathrm{P}$ and $\mathrm{K}$ was found in weedy check throughout the crop season that was significantly higher over rest of the weed management treatments (Table 2). Whereas, it was found that all weed control treatments significantly reduced the $\mathrm{N}, \mathrm{P}$ and $\mathrm{K}$ uptake by total weeds at $60 \mathrm{DAS}$. The lowest $(1.44,0.25$ and $1.34 \mathrm{~kg} / \mathrm{ha})$ total uptake of $\mathrm{N}, \mathrm{P}$ and $\mathrm{K}$ by weeds was recorded with treatment two hand weeding at 25 and 45 DAS (W3), which was at par with Pendimethalin @ 750 g a.i./ha (PE) + Imazethapyr @ $75 \mathrm{~g}$ a.i./ha (PoE), pendimethalin (PE) @ $750 \mathrm{~g}$ a.i./ha + quizalofop-p-ethyl @ $37.5 \mathrm{~g}$ a.i./ha (PoE), pendimethalin $30 \mathrm{EC}+$ imazethapyr 2 EC (RM) @ 750 g a.i./ha as (PoE) and superior to rest over treatments during the experimentation. The drastic reduction in nutrient depletion by weeds under these treatments might be directly associated with the corresponding reduction in dry matter production by weeds due to effective control and suppression of weed growth by crop. Nutrient uptake is the product of per cent nutrient content and biomass, thus similarity in the trend of uptake and total weed biomass production was an expected outcome. Reduced nutrient uptake by weeds under the influence of different weed control measures had been also reported by Reager et al., (2003) and Yadav et al., (2011).

On the basis of the findings of the present investigation, it can be concluded that both hand weedings at 25 and 45 DAS and pendimethalin @ 750 g a.i./ha (PE) + imazethapyr @ 75 g a.i./ha (PoE) treatments were found significantly superior in reducing weed density, dry weight and nutrient depletion by weeds as well as higher weed control efficiency than weedy check and all other single herbicide applied treatments. Preemergence application of pendimethalin @ $750 \mathrm{~g}$ a.i./ha + post emergence imazethapyr @ $75 \mathrm{~g}$ a.i./ha was found to be the best superior treatment for obtaining higher grain yield $(1345 \mathrm{~kg} / \mathrm{ha})$ in clusterbean. Two hand weeding at 25 and 45 DAS also proved equally effective in grain yield (1385 kg/ha).

\section{Acknowledgements}

The authors are thankful to Head, Department of Agronomy, S.K.N. College of Agriculture, Jobner for providing field staff, facilities and assistance in conducting this research.

\section{References}

Anonymous, 2016-17a. Agricultural Statistics at a Glance. Directorate of Economics and Statistics, Department of Agriculture and Cooperation, Ministry of Agriculture, New Delhi.

Anonymous, 2016-17b. Rajasthan Agricultural Statistics at a Glance. Department of Agriculture, Pant Krishi Bhawan, Jaipur, Rajasthan.

Bhadoria, R.B.S., Jain, P.C. and Tomar, S.S. 2000. Crop-weed competition in clusterbean (Cyamopsis tetragonoloba) under rainfed condition. Indian Journal of Agronomy 45(4): 737-739.

Jackson, M.L. 1973. Soil Chemical Analysis. Prentice Hall of India Pvt. Ltd. New Delhi, pp.498.

Jha, A.K. and Soni Monika 2013. Weed management by sowing methods and herbicides in Soybean. Indian Journal of Weed Science 45(4): 250- 252.

Linder, R.C. 1944. Rapid analytical method for some of the more common inorganic constituents of plant tissue. Plant Physiology 19:70-89.

Patel, B.D., Patel, R.B., Meisuriya, M.I. and 
Patel, M.V. 2005. Integrated weed management in cluster bean (Cyamopsis tetragonoloba L.). National Biennial Conference, ISWS, P A U, April 6-7: 154-156.

Punia, S.S., Singh, S. and Yadav, D. 2011. Bio efficacy of imazethapyr and chlorimuron-ethyl in clusterbean and their residual effect on succeeding crops. Indian Journal of Weed Science 43(1 and 2): 48-53.

Raju, S., Pandit, S., Rathod, B.M., Ananda, N. and Patil, R.P. 2017. Bio efficacy of herbicides against weeds of blackgram grown under rainfed conditions. Journal of Farm Sciences 30(1): 3740.

Reager, M.L., Choudhary, G.R. and Dahama, A.K. 2003, Effect of weed control and phosphorus on growth and quality of cluster bean [Cyamopsis tetragonoloba (L.) Taub]. Annals of Agricultural Research 24(3): 563-566.

Richards, L.A. 1968. Diagnosis and improvement of saline and alkali soil. United States Department of Agriculture. Hand Book No. 60,
Oxford and IBH Publishing Company, New York.

Singh, M., Shekhar, K. S., Ardeep and Datta, D. 2018. Herbicide combinations for weed management in Urdbean (Vigna mungo) under tarai condition of Uttarakhand. International Journal of Chemical Studies 6(4):1594-1597.

Sonani, V.V., Patil, R.R. and Patil, J.A 1985. Critical period of crop-weed competition in guar [Cyamopsis tetragonoloba (L.) Taub.]. Annual conf. Indian Society of Weed Science pp. 84.

Varshney Jay, G. 1990. Chemical control of weeds in Soybean. Indian Journal of Weed Science, 22: 17-22.

Yadav, J.P. and Mishra, M.R.C. 1982. Naven Prayogic Krishi, Kanti Prakashan, Etawa.

Yadav, S.L., Kaushik, M.K. and Mundra, S.L. 2011. Effect of weed control practices on weed dry weight, nutrient uptake and yield of clusterbean [Cyamopsis tetragonoloba (L.) Taub.] under rainfed condition. Indian Journal of Weed Science 43(1 and2): 81-84.

\section{How to cite this article:}

Bharat Lal Meena, B. L. Dudwal, Kamal Garg, Monu Jorwal and Ram Krishna Shekhawat. 2021. Effect of Weed Management Practices on Weed Studies, Yield and Nutrient Depletion in Clusterbean [Cyamopsis tetragonoloba (L.) Taub]. Int.J.Curr.Microbiol.App.Sci. 10(02): 31193127. doi: https://doi.org/10.20546/ijcmas.2021.1002.341 